\title{
Deterioration resistance Behavior of Carbon Metal in Salt Water by Alanine- $\mathrm{Zn}^{2+}$ System
}

\author{
${ }^{1}$ S. Gowri, ${ }^{2}$ J. Sathiyabama \\ ${ }^{1}$ PG Department of Chemistry, St. Antonys's College of Arts and Sciences For Women, \\ Thamaraipadi, Dindigul, Tamilnadu, India. gowrisri2411@gmail.com \\ ${ }^{2}$ Research Dean, PG and Research Department of Chemistry, Corrosion Research Centre, GTN \\ Arts College, Dindigul, TamilNadu, India.
}

Abstract - The inhibition effectiveness of Alanine - $\mathrm{Zn}^{2+}$ system in scheming deterioration of carbon steel in salt water has been evaluate by mass loss method. The formulation consisting of $250 \mathrm{ppm}$ of Alanine and $25 \mathrm{ppm}$ of $\mathrm{Zn}^{2+} \mathrm{has} 87 \%$ IE. A synergistic effect exists among Alanine and $\mathrm{Zn}^{2+}$. Polarization analysis reveals to facilitate the Alanine - $\mathrm{Zn}^{2+}$ system function as an anodic inhibitor and the formulation controls the anodic reaction mostly. The character of the shielding film on metal shell has been analyzed by AFM analysis.

Keywords: AFM, Amino acids, Alanine, Carbon Steel, Electro chemical techniques, Seawater.

\section{INTRODUCTION}

Corrosion is a process through which metals in manufactured states return to their natural oxidation states. This process is a reduction-oxidation reaction in which the metal is being oxidized by its surroundings, often the oxygen in air. This reaction is both spontaneous and electrochemically favored. Corrosion is essentially the creation of voltaic, or galvanic, cells where the metal. [1-3]. Various techniques have been used to evaluate the corrosion inhibition efficiency of amino acids and to analyze the nature of protective film formed on the metal surface. Depending on the nature of metal and nature of corrosive environment amino acids obeys different types of isotherms and behaves as different type of inhibitor, namely, anodic, cathodic or mixed type.[4]

Amino acids have the ability to manage the deterioration of dissimilar metals.[5-8]

Normally amino acids contain two polar groups, namely, one amino group and one carboxyl group. It preserve harmonize with metals during the nitrogen atom and oxygen atom of the carboxyl group. A review of the existing literature reveals that the corrosion selfconsciousness by amino acids (Glycine, alanine, glatamic acid and methionine) on copper, Carbon metal and Aluminium electrode in aqueous medium has been investigated.[6]

\section{The present work is under taken;}

1. To estimate the self-consciousness effectiveness of Alanine- Zn2+ system in controlling deterioration of carbon metal immerse in the absence and presence of $\mathrm{Zn} 2+$ by mass loss method.
2. To examine the mechanistic aspects of corrosion inhibition by means of electrochemical studies like polarization study.

3. To investigate the shielding film by AFM.

\section{Experimental}

Carbon metal specimens $[0.0267 \% \mathrm{~S}, 0.06 \% \mathrm{P}, 0.4 \% \mathrm{Mn}$, $0.1 \% \mathrm{C}$ and the rest iron] of dimensions $1.0 \mathrm{~cm} \mathrm{x} 4.0 \mathrm{~cm} \mathrm{x}$ $0.2 \mathrm{~cm}$ were refined to a mirror finish and degreased with trichloroethylene.

\section{Weight loss method}

Carbon metal specimens were immerse in $100 \mathrm{~mL}$ of the salt water containing different concentrations of the inhibitor in the presence and absence of $\mathrm{Zn} 2+$ for one day. The mass of the specimens before and after immersion was resolute using a Shimadzu balance, model AY62. The deterioration products were cleansed with Clarke's solution17. The inhibition effectiveness (IE) was then intended using the equation:

$\mathrm{IE}=100[1-(\mathrm{W} 2 / \mathrm{W} 1)] \%$

Where $\mathrm{W} 1$ = corrosion rate in the absence of the inhibitor, $\mathrm{W} 2=$ corrosion rate in the presence of the inhibitor.

\section{Potentiodynamic polarization}

Polarization study was carry out in a CHI- electrochemical work station with impedance model 660A. It was provided with iR compensation facility. A three electrode cell assembly was used. The working electrode was carbon metal. A SCE was the reference electrode. Platinum was the counter electrode. From polarisation study, corrosion parameters such as corrosion potential (Ecorr), corrosion current (Icorr), Tafel slopes anodic $=\mathrm{ba}$ and cathodic $=\mathrm{bc}$ 
and LPR value. The scan rate (V/S) was 0.01 . Hold time at (Efcs) was zero and quiet time (s) was two.

\section{Atomic Force Microscopy characterization (AFM)}

The carbon metal specimen immersed in blank and in the inhibitor solution for a period of one day was removed, rinsed with double distilled water, dried and subjected to the surface examination. Atomic force microscopy (Veeco dinnova model) was used to observe the samples' surface in tapping mode, using cantilever with linear tips. The scanning area in the images was $5 \mu \mathrm{m} \times 5 \mu \mathrm{m}$ and the scan rate was $0.6 \mathrm{HZ} /$ second.

\section{RESUltS AND DISCUSSION}

\section{Analysis of Weight loss Study}

Corrosion rate $(\mathrm{CR})$ of carbon steel immersed in sea water in the absence and presence of inhibitors (Alanine and $\mathrm{Zn}^{2+}$ system):

The calculated corrosion inhibition efficiency (IE) and corrosion rates (CR) of Ala in controlling corrosion of carbon steel in sea water, for a period of one day in absence and presence of $\mathrm{Zn}^{2+}$ are given in Table 1 .
It is observed from the Table 1, that the calculated value indicates the ability of Alanine to be a good inhibitor. The IE is found to be enhanced in the presence of $\mathrm{Zn}^{2+}$. Ala alone shows some inhibition efficiencies. $50 \mathrm{ppm}$ of Alanine shows $15 \%$ of IE, as the concentration of Alanine increases, the IE also increases. Similarly for a given concentration of Alanine the IE increases as the concentration of $\mathrm{Zn}^{2+}$ increases. A synergistic effect exists between Alanine and $\mathrm{Zn}^{2+}$. For example, $25 \mathrm{ppm}$ of $\mathrm{Zn}^{2+}$ has $64 \%$ of IE; $250 \mathrm{ppm}$ of L-Ala has $35 \%$ IE. Interestingly their combination has high IE, namely, $87 \%$.

Therefore the mixture of inhibitors shows better IE than individual inhibitors. In the presence of $\mathrm{Zn}^{2+,}$ more amount of Alanine is transported towards the metal surface. $\mathrm{Fe}^{2+}$ L-Ala complex is formed on the anodic sites of the metal surface. Thus the anodic reaction is controlled. The cathodic reaction is the generation of $\mathrm{OH}^{-}$, which is controlled by the formation of $\mathrm{Zn}(\mathrm{OH})_{2}$ on the cathodic sites of the metal surface. This accounts for the synergistic effect existing between $\mathrm{Zn}^{2+}$ and Alanine. [1-6]

Table 1 Inhibition efficiencies (IE) and corrosion rates (CR) obtained from Alanine- $\mathrm{Zn}^{2+}$ systems, when the carbon steel immersed in sea water

Inhibitor system: Alanine- $\mathrm{Zn}^{2+}$

\section{Immersion period: 1 day}

\begin{tabular}{|c|c|c|c|c|c|c|c|c|}
\hline \multirow[t]{2}{*}{ Alanine (ppm) } & \multicolumn{2}{|r|}{ (0 ppm) } & \multicolumn{2}{|c|}{$\begin{array}{c}\mathrm{Zn}^{2+} \\
(15 \mathrm{ppm})\end{array}$} & \multicolumn{2}{|c|}{$\begin{array}{c}\mathrm{Zn}^{2+} \\
(20 \mathrm{ppm})\end{array}$} & \multicolumn{2}{|c|}{$\begin{array}{c}\mathrm{Zn}^{2+} \\
(25 \mathrm{ppm})\end{array}$} \\
\hline & IE \% & CR mmpy & IE \% & CR mmpy & IE\% & $\begin{array}{c}\text { CR } \\
\text { mmpy }\end{array}$ & IE\% & $\begin{array}{c}\text { CR } \\
\text { mmpy }\end{array}$ \\
\hline 0 & - & 0.1809 & 41 & 0.1067 & 41 & 0.1607 & 64 & 0.0651 \\
\hline 50 & 15 & 0.1538 & 42 & 0.1049 & 43 & 0.1031 & 66 & 0.0615 \\
\hline 100 & 17 & 0.1501 & 42 & 0.1049 & 48 & 0.0941 & 69 & 0.0561 \\
\hline 150 & 25 & 0.1357 & 45 & 0.0995 & 52 & 0.0868 & 73 & 0.0488 \\
\hline 200 & 31 & 0.1248 & 46 & 0.0967 & 57 & 0.0778 & 81 & 0.0344 \\
\hline 250 & 35 & 0.1176 & 49 & 0.0923 & 62 & 0.0687 & 87 & 0.0235 \\
\hline
\end{tabular}

Analysis of polarization curves of Alanine $-\mathrm{Zn}^{2+}$ system

Polarization analysis has been used to detect the formation of protective film on the metal surface during corrosion inhibition process. The calculated corrosion parameters such as corrosion potential $\left(\mathrm{E}_{\mathrm{corr}}\right)$, tafel slopes (anodic slope $\mathrm{b}_{\mathrm{a}}$ and cathodic slope $\mathrm{b}_{\mathrm{c}}$ ), Linear polarization resistances (LPR) and corrosion current $\left(\mathrm{I}_{\text {corr }}\right)$ values are given in the Table 2 The potentiodynamic polarization curves of carbon steel immersed in sea water in the absence and presence of inhibitors are shown in Fig 1.

When the carbon steel is immersed in the sea water the corrosion potential is $-784 \mathrm{mV}$ vs SCE (saturated calomel electrode). The inhibitor system (Alanine $(250 \mathrm{ppm})-\mathrm{Zn}^{2+}(25 \mathrm{ppm})$ ) shifts the corrosion potential to $-774 \mathrm{mV}$ vs SCE. This indicates that the anodic reaction is controlled predominantly. The corrosion current value and the LPR values for sea water are $7.042 \times 10^{-6}$ $\mathrm{A} / \mathrm{cm}^{2}$ and $5.375 \times 10^{3} \Omega \mathrm{cm}^{2}$ respectively. In the presence of inhibitors, the corrosion current value decreases to $6.202 \times 10^{-6}$ $\mathrm{A} / \mathrm{cm}^{2}$ and the LPR value has increased to $6.124 \times 10^{3} \Omega \mathrm{cm}^{2}$. This indicates that a protective film formed on the metal surface. [7]. 


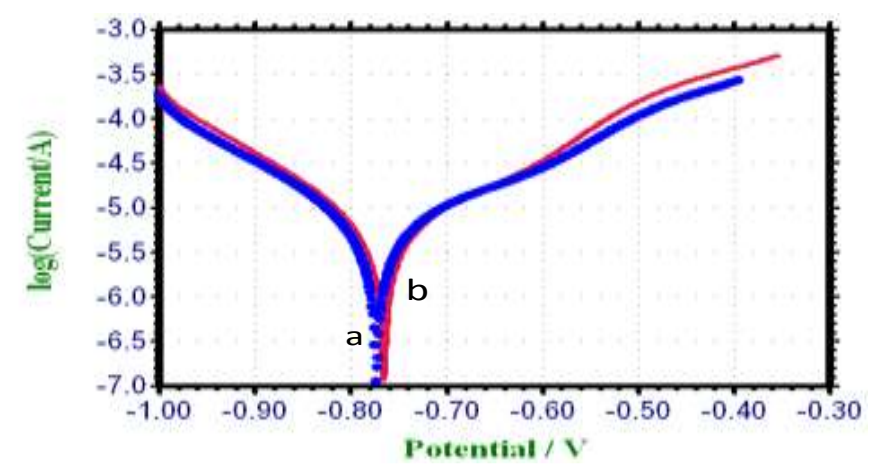

Fig 1. Polarization curves of carbon steel immersed in various test solutions

(a) Sea water

(b) Sea water $+250 \mathrm{ppm}$ of Alanine $+25 \mathrm{ppm}$ of $\mathrm{Zn}^{2+}$

Table 2. Corrosion parameters of carbon steel immersed in sea water in the presence and absence of inhibitor obtained by polarization method

\begin{tabular}{|c|c|c|c|c|c|c|}
\hline Alanine (ppm) & $\mathrm{Zn}^{2+}(\mathbf{p p m})$ & $\begin{array}{c}\mathbf{E}_{\text {corr }} \\
(m V \text { vs } S C E)\end{array}$ & $\begin{array}{c}\mathbf{I}_{\text {corr }} \\
\left(\mathbf{A c m}^{-2}\right)\end{array}$ & $\left(m V^{b_{a}} \operatorname{dec}^{-1}\right)$ & $\left.\mathbf{b}_{\mathrm{c}} \operatorname{dec}^{-1}\right)^{(\mathrm{mV}}$ & $\left(\Omega \mathrm{cm}^{2}\right)$ \\
\hline 0 & 0 & -784 & $7.042 \times 10^{-6}$ & 232 & 139 & $5.375 \times 10^{3}$ \\
\hline 250 & 25 & -774 & $6.202 \times 10^{-6}$ & 215 & 147 & $6.124 \times 10^{3}$ \\
\hline
\end{tabular}

Analysis of AC impedance Spectra for Alanine- $\mathrm{Zn}^{2+}$ system

AC impedance spectra have been used to detect the formation of protective film on the metal surface. Nyquist plot representation of carbon steel immersed in sea water in the absence and presences of inhibitors are shown in the Fig 2 . The impedance parameters such as charge transfer resistance $\left(R_{t}\right)$ and double layer capacitance $\left(C_{d l}\right)$ values are given in the Table If a protective film formed on the metal surface, the charge transfer resistance $\left(R_{t}\right)$ and double layer capacitance value decreases. It is clear from the plots that the impedance response of carbon steel significantly changed after addition of the inhibitors. The impedance diagram obtaines almost semicircular appearance. This indicates that the corrosion of carbon steel in aqueous solution is mainly controlled by a charge transfer process. The deviation from the perfect semicircle shape is due to the frequency dispersion of interfacial impedance. This anomalous behavior is generally due to the non- homogeneity of the metal surface arising from surface roughness or interfacial phenomena.

From the table the $R_{t}$ value is $120.22 \Omega \mathrm{cm}^{2}$ and $\mathrm{C}_{\mathrm{dl}}$ value is $4.242 \times 10^{-8} \mathrm{~F} / \mathrm{cm}^{2}$. When L-Ala $(250 \mathrm{of} \mathrm{ppm})$ and $\mathrm{Zn}^{2+}(25$ of ppm) are added to sea water, $R_{t}$ value increases from $120.22 \Omega \mathrm{cm}^{2}$ to $129.46 \Omega \mathrm{cm}^{2}$. The $\mathrm{C}_{\mathrm{dl}}$ value decreases from $4.242 \times 10^{-8}$ $\mathrm{F} / \mathrm{cm}^{2}$ to $3.939 \times 10^{-8} \mathrm{~F} / \mathrm{cm}^{2}$. This confirms that the formation of protective film on the metal surface. This accounts for the very high IE of Alanine $-\mathrm{Zn}^{2+}$ system.[8]

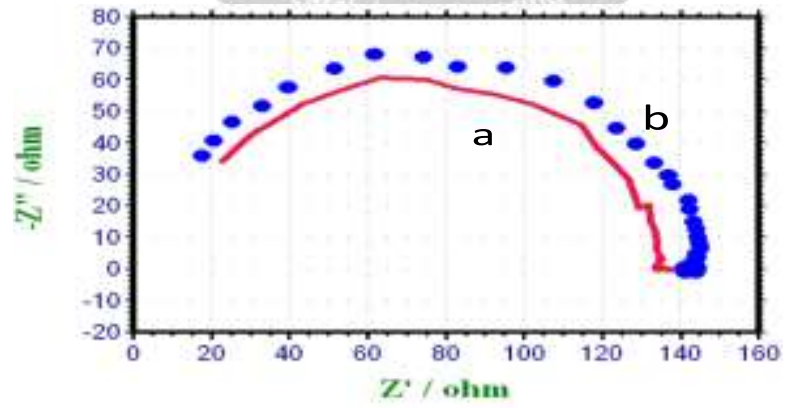

Fig 2 AC impedance spectra of carbon steel immersed in various test solutions (Nyquist plots)

(a) Sea water

Sea water $+\mathrm{L}$-Ala $(250 \mathrm{ppm})+\mathrm{Zn}^{2+}(25 \mathrm{ppm})$

Table 3. Impedance parameters of carbon steel immersed in sea water in the absence and presences of inhibitors obtained by AC impedance spectra

\begin{tabular}{|c|c|c|c|}
\hline L-Ala (ppm) & $\mathbf{Z n}^{2+}(\mathbf{p p m})$ & $\mathbf{R}_{\mathbf{t}}\left(\mathbf{\Omega} \mathbf{c m}^{2}\right)$ & $\mathbf{C}_{\mathrm{dl}}\left(\mathbf{F} / \mathbf{c m}^{2}\right)$ \\
\hline 0 & 0 & 120.22 & $4.242 \times 10^{-8}$ \\
\hline 250 & 25 & 129.46 & $3.939 \times 10^{-8}$ \\
\hline
\end{tabular}




\section{Atomic Force Microscopy Characterization}

Atomic force microscopy (AFM) or scanning force microscopy (SFM) is a very high-resolution type of scanning probe microscopy, with demonstrated resolution on the order of fractions of a nanometer, more than 1000 times better than the optical diffraction limit. AFM is a powerful technique for the gathering of roughness statistics from a variety of surfaces. AFM becoming an accepted method of roughness investigation

The two dimensional (2D), three dimensional (3D) AFM morphologies and AFM cross- sectional profile for polished carbon steel surface (reference sample), carbon steel surface immersed in sea water (blank sample) and the carbon steel surface immersed in sea water containing Alanine (250 ppm) $-\mathrm{Zn}^{2+}(25 \mathrm{ppm})$ are shown in Figs.3.1, 3.2 and 3.3 respectively.

\section{Root- mean-square roughness, average roughness and peak-to-valley value}

AFM image analysis was performed to obtain the average roughness, $\mathrm{R}_{\mathrm{a}}$ (the average deviation of all points roughness profile from a mean line over the evaluation length), root-mean-square roughness, $R_{q}$ (the average of the measured height deviations taken within the evaluation length and measured from the mean line) and the maximum peak-to-valley (P-V) height values (Largest single peak-to-valley height in five adjoining sampling heights). $\mathrm{R}_{\mathrm{q}}$ is much more sensitive than $\mathrm{R}_{\mathrm{a}}$ to Large and small height deviations from the mean.

The $\left(\mathrm{R}_{\mathrm{q}}\right),\left(\mathrm{R}_{\mathrm{a}}\right),(\mathrm{P}-\mathrm{V})$ value for carbon steel surface immersed in different environment are summarized in Table

In Fig.3.1a. 3.2a, 3.3a the surface topography of uncorroded metal surface is shown. The values of $R_{q}, R_{a}$ and P-V height for the polished carbon steel surface (reference sample) are $4.33 \mathrm{~nm}, 3.41 \mathrm{~nm}$ and $35.28 \mathrm{~nm}$ respectively. The data indicates a homogeneous surface. The slight roughness observed on the polished carbon steel surface is due to the atmospheric corrosion.

Figs.3.1b, 3.2b and 3.3b shows the pitted, corroded metal surface in the absence of the inhibitor immersed in sea water. The $\mathrm{R}_{\mathrm{q}}$, $R_{a}$ and P-V height values for carbon steel surface are $40.2 \mathrm{~nm}, 31 \mathrm{~nm}$ and $191.9 \mathrm{~nm}$ respectively. These data suggest that carbon steel surface immersed in sea water has a far greater surface roughness than the polished metal surface, which shows that the unprotected carbon steel surface is rough due to the corrosion of the carbon steel in sea water environment.

Figs.3.3c, 3.4c and 3.3c show the steel surface after immersion in sea water containingL-Ala $(250 \mathrm{ppm})-\mathrm{Zn}^{2+}(25 \mathrm{ppm})$. The $R_{q}, R_{a}$ and P-V height values for carbon steel surface are $32.2 \mathrm{~nm}, 24.1 \mathrm{~nm}$ and $130.5 \mathrm{~nm}$ respectively. The $R_{q}, R_{a}$ and $P-V$ height values are considerably less in the inhibited environment compared to the uninhibited environment. These parameters confirm that the surface is smoother. The smoothness of the surface is due to the formation of a compact protective film of $\mathrm{Fe}^{2+}$-L-Ala complex and $\mathrm{Zn}(\mathrm{OH})_{2}$ on the metal surface, thereby inhibiting the corrosion of carbon steel.

Also the increase in $\mathrm{R}_{\mathrm{q}}, \mathrm{R}_{\mathrm{a}}$ and $\mathrm{P}-\mathrm{V}$ values for carbon steel immersed in sea water in the presence of inhibitors, which are somewhat greater than the $\mathrm{R}_{\mathrm{q}}, \mathrm{R}_{\mathrm{a}}$ and $\mathrm{P}-\mathrm{V}$ height values of polished metal surface, confirms the presence of the film on the metal surface, which is protective in nature.[9] 


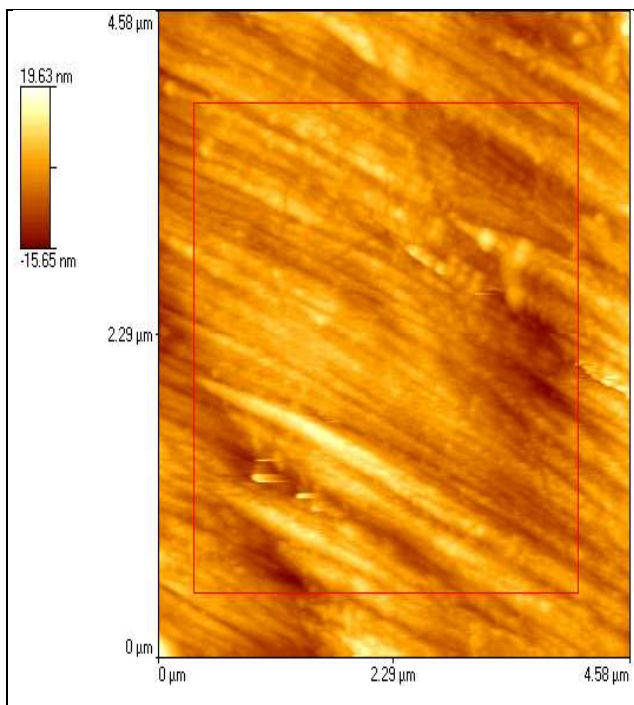

(a)

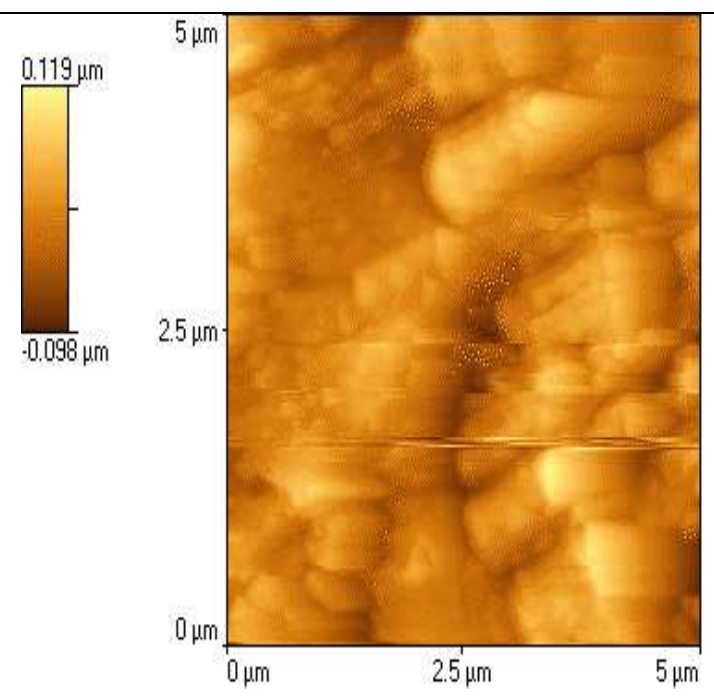

(b)

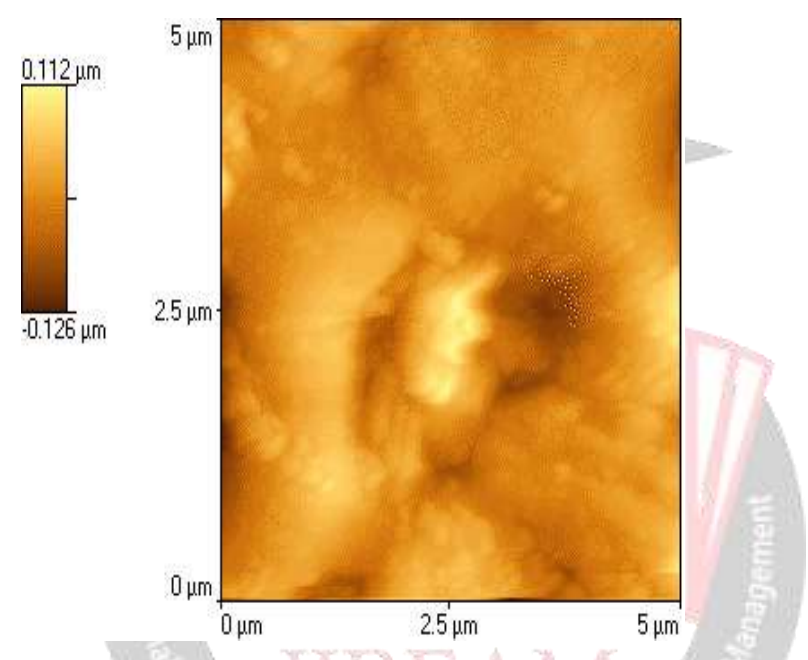

(c)

Fig. 3.1. Two dimensional AFM image of the surface

a) Polished carbon steel (control)

b) Carbon steel immersed in sea water (blank)

c) Carbon steel immersed in sea water containing Alanine $(250 \mathrm{ppm})+\mathrm{Zn}^{2+}(25 \mathrm{ppm})$ 


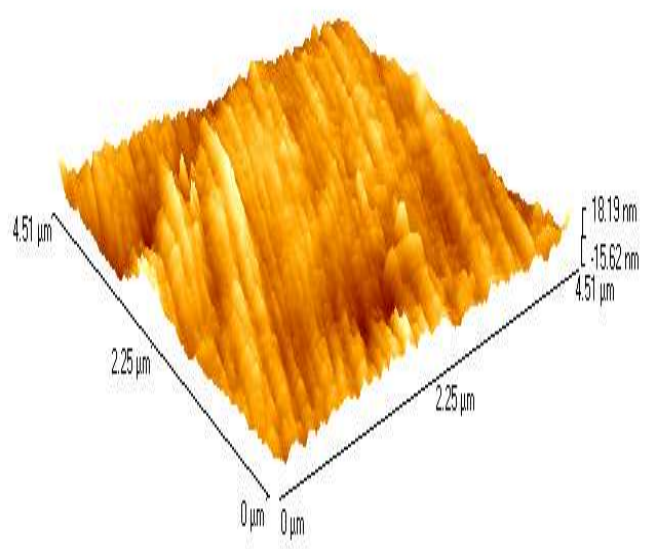

(a)

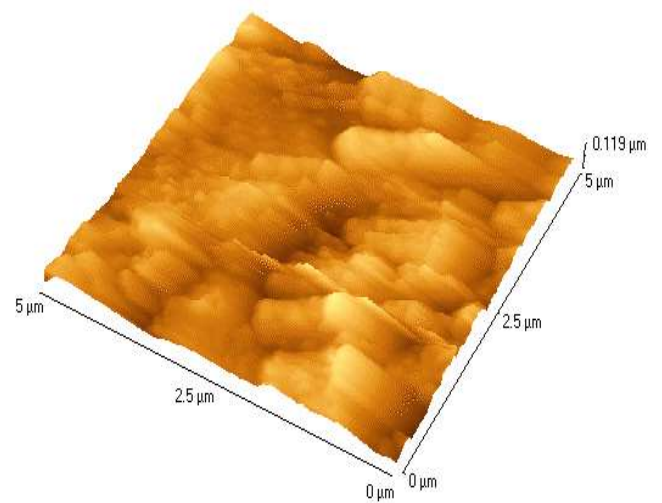

(b)

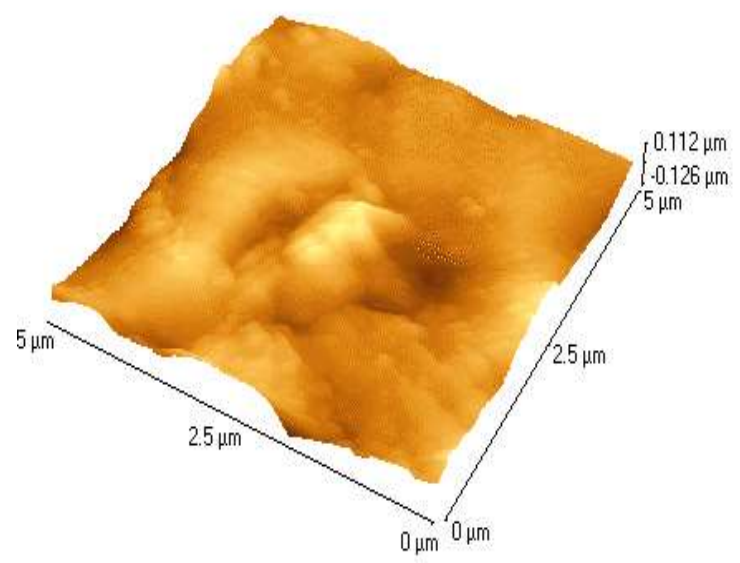

(c)

Fig3.2. Three dimensional AFM images of the surface of

a) Polished carbon steel (control)

b) Carbon steel immersed in sea water (blank)

c) Carbon steel immersed in sea water Alanine $(250 \mathrm{ppm})+\mathrm{Zn}^{2+}(25 \mathrm{ppm})$ 


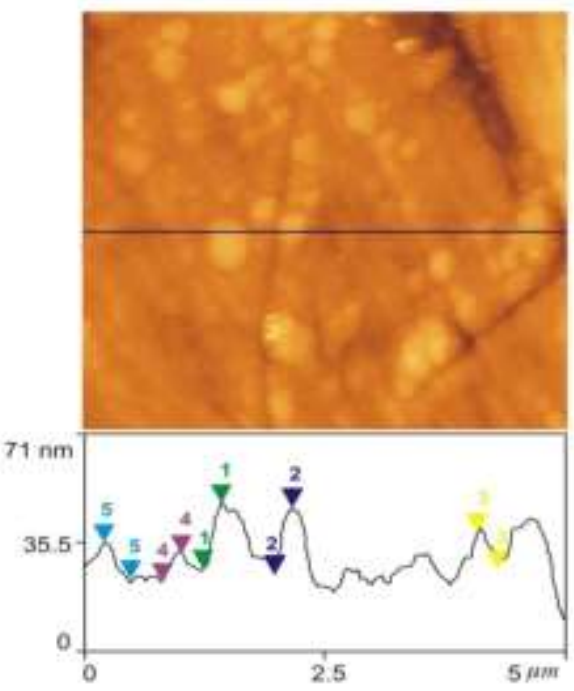

(a)

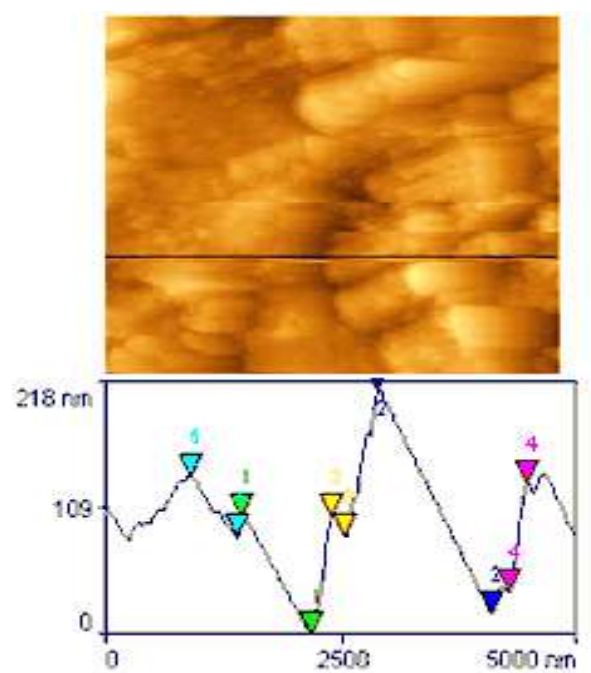

(b)

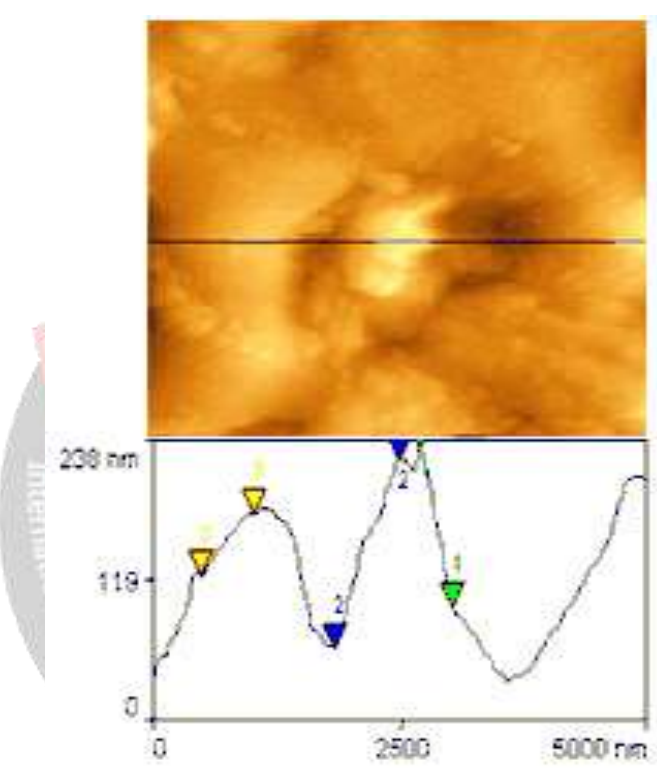

(c)

Fig.3.3 AFM cross sectional image of the surface of

a) Polished carbon steel (control)

b) Carbon steel immersed in sea water (blank)

c) Carbon steel immersed in sea water containing Alanine $(250 \mathrm{ppm})+\mathrm{Zn}^{2+}(25 \mathrm{ppm})$

Table 4. AFM data for carbon steel surface immersed in inhibited and uninhibited environment

\begin{tabular}{|c|c|c|c|}
\hline Sample & $\begin{array}{c}\operatorname{RMS}\left(\mathbf{R}_{\mathrm{q}}\right) \\
\text { Roughness } \\
(\mathbf{n m})\end{array}$ & $\operatorname{Average}\left(\mathbf{R}_{\mathrm{a}}\right)$ Roughness $(\mathbf{n m})$ & $\begin{array}{c}\text { Maximum Peak-to-valley height } \\
\text { (nm) }\end{array}$ \\
\hline 1.Polished carbon steel & 4.33 & 3.41 & 35.28 \\
\hline 2.Carbon steel immersed in sea water (blank) & 40.2 & 31.0 & 191.1 \\
\hline $\begin{array}{l}\text { 3.Carbon steel immersed in sea water }+250 \mathrm{ppm} \text { of } \\
\text { Alanine+ } 25 \mathrm{ppm} \mathrm{Zn}^{2+}\end{array}$ & 32.2 & 24.1 & 130.5 \\
\hline
\end{tabular}




\section{MECHANISM OF CORROSION INHIBITION}

The results of weight loss study shows that the formulation consisting of $250 \mathrm{ppm}$ of Alanine and $25 \mathrm{ppm}$ of $\mathrm{Zn}{ }^{2+}$ has $87 \%$ IE, in controlling corrosion of carbon steel in sea water. A synergistic effect exists between Alanine and $\mathrm{Zn}^{2+}$. The polarization study reveals that the Alanine- $\mathrm{Zn}^{2+}$ system functions as anodic inhibitor controlling anodic reaction predominantly and controls cathodic reaction to some extent. AC impedance spectra and AFM analysis reveals that the formation of protective film on the metal surface.

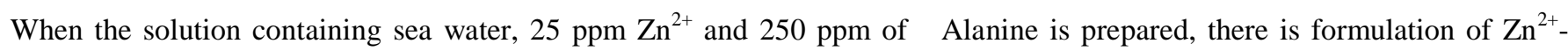
Alanine complex in solution.

$>$ When the carbon steel is immersed in this solution, the $\mathrm{Zn}^{2+}$ - Alanine complex diffuses from the bulk of the solution towards metal surface.

$>\mathrm{Zn}^{2+}$ - Alanine complex diffuses from the bulk of the solution to the surface of the metal and is converted into a Fe ${ }^{2+}-$ Alanine complex, which is more stable than $\mathrm{Zn}^{2+-}$ Alanine.

$>$ On the metal surface $\mathrm{Zn}^{2+}$ - Alanine complex is converted in to $\mathrm{Fe}^{2+}-\mathrm{L}-\mathrm{Ala}$ on the anodic sites. $\mathrm{Zn}^{2+}$ is released.

$$
\mathrm{Zn}^{2+} \text { - Alanine }+\mathrm{Fe}^{2+}-------\rightarrow \mathrm{Fe}^{2+}-\text { Alanine }+\mathrm{Zn}^{2+}
$$

$>$ The released $\mathrm{Zn}^{2+}$ combines with $\mathrm{OH}^{-}$to form $\mathrm{Zn}(\mathrm{OH})_{2}$ bn the cathodic sites.

$$
\mathrm{Zn}^{2+}+\mathrm{OH}^{-}------\rightarrow \mathrm{Zn}(\mathrm{OH})_{2}
$$

Thus the protective film consists of $\mathrm{Fe}^{2+}$ - Alanine complex and $\mathrm{Zn}(\mathrm{OH})_{2}$.

\section{CONCLUSION}

The inhibition effectiveness of Alanine $-\mathrm{Zn}^{2+}$ system in scheming deterioration of carbon metal in salt water has been evaluate by mass loss method. The formulation consisting of $250 \mathrm{ppm}$ of Alanine and $25 \mathrm{ppm}$ of $\mathrm{Zn}^{2+}$ has $87 \%$ IE. A synergistic effect exists among Alanine and $\mathrm{Zn}^{2+}$. Polarization analysis reveals to facilitate the Alanine $-\mathrm{Zn}^{2+}$ system function as an anodic inhibitor and the formulation controls the anodic reaction mostly. The character of the shielding film on metal shell has been analyzed by AFM analysis

\section{REFERENCE}

[1] Landolt, Dieter. Corrosion and Surface Chemistry of Metals. EPFL Press, 2007.

[2] Perez, Nestor. Electrochemistry and Corrosion Science . Kluwer Academic Publishers, 2004.

[3] Petrucci, Ralph H., William S. Harwood, F G. Herring, and Jeffry D. Madura. General Chemistry Principles and Modern Applications. 9th ed. New Jersey: Pearson Education, Inc, 2007.

[4] S. Gowri, J. Sathiyabama, 2012, 1(11), 470-476.

[5] Eddy N.O., Journal of Advanced Research, 2011, 2(1), 35-47.

[6] Gece G., Bilgiç S., Corrosion Science, 2010, 52(10), 3435-3443

[7] Khaled K.F, Corrosion Science, 2010, 52(10), 3225-3234.

[8] Tkalenko D.A., Venkatesvaran G., Vishevskaya Yu.P., Keny S.J., Byk M.V., Muthe K., Protection of Metals and Physical Chemistry of Surfaces, 2010, 46(5), 609-614.

[9] S.Gowri, Corrosion Inhibition of Carbon Steel in Sea Water by Glutamic Acid - Zn2+ System, Chem Sci Trans., 2013, 2(1), 275-281 Chemical Science Transactions. 